\title{
The impact of biogenic carbon sources on aerosol absorption in Mexico City
}

\author{
N. A. Marley ${ }^{1}$, J. S. Gaffney ${ }^{2}$, M. Tackett ${ }^{2}$, N. C. Sturchio ${ }^{3}$, L. Heraty ${ }^{3}$, N. Martinez ${ }^{3}$, K. D. Hardy ${ }^{4}$, \\ A. Marchany-Rivera ${ }^{5}$, T. Guilderson ${ }^{6}$, A. MacMillan ${ }^{7}$, and K. Steelman ${ }^{7}$ \\ ${ }^{1}$ Graduate Institute of Technology, University of Arkansas at Little Rock, Little Rock, AR, USA \\ ${ }^{2}$ Chemistry Department, University of Arkansas at Little Rock, Little Rock, AR, USA \\ ${ }^{3}$ Earth and Environmental Sciences, University of Illinois at Chicago, Chicago, IL, USA \\ ${ }^{4}$ Swarthmore College, 500 College Ave., Swarthmore, PA, USA \\ ${ }^{5}$ University of Puerto Rico, Mayaguez, Mayaguez, PR, Puerto Rico \\ ${ }^{6}$ Center for Accelerator Mass Spectrometry, Lawrence Livermore National Laboratory, Livermore, CA, USA \\ ${ }^{7}$ Chemistry Department, University of Central Arkansas, Conway, AR, USA
}

Received: 13 August 2008 - Published in Atmos. Chem. Phys. Discuss.: 24 October 2008

Revised: 30 January 2009 - Accepted: 31 January 2009 - Published: 2 March 2009

\begin{abstract}
In order to determine the wavelength dependence of fine ( $<1$ micron) atmospheric aerosol absorption in the Mexico City area, the absorption Ångstrom exponents (AAEs) were calculated from hourly averages of aerosol absorption measured at seven wavelengths $(370,450,520$, $590,660,880$, and $950 \mathrm{~nm}$ ) with an aethalometer during two field campaigns, the Mexico City Metropolitan Area study in April 2003 (MCMA 2003) and the Megacity Initiative: Local and Global Research Observations in March 2006 (MILAGRO). These results were compared to AAEs determined in the laboratory from $850-280 \mathrm{~nm}$ (350 points) on 12-h fine aerosol samples collected at the same sites. The aerosol AAEs varied from 0.76 to 1.5 in 2003 and from 0.63 to 1.4 in 2006. The AAE values determined in the afternoon were consistently higher than the corresponding morning values, suggesting the photochemical aging of the aerosols leading to the formation of more highly UV absorbing organic aerosol species in the afternoon.

The AAE values were compared to stable and radiocarbon isotopic measurements of the 12-h aerosol samples to determine the sources of the aerosol carbon. The fraction of modern carbon (fM) in the aerosol samples, as determined from ${ }^{14} \mathrm{C}$ analysis, showed that an average of $70 \%$ of the carbonaceous aerosols in Mexico City were from modern biomass sources during both field campaigns. The ${ }^{13} \mathrm{C} /{ }^{12} \mathrm{C}$ ratios of
\end{abstract}

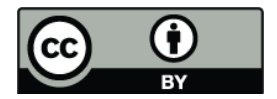

Correspondence to: J. S. Gaffney (jsgaffney@ualr.edu) the aerosol carbon illustrate the significant impact of Yucatan forest fires (C-3 plants) in 2003 and local grass fires (C-4 plants) in 2006. A direct comparison of the fM values, stable carbon isotope ratios, and aerosol AAEs suggested that the wavelength dependence of the aerosol absorption was controlled by the biogenically derived aerosol components.

\section{Introduction}

Atmospheric aerosols play an important role in global climate because of their ability to both scatter and absorb solar radiation. While aerosol scattering is primarily dependent on particle size, aerosol absorption is largely dependent upon chemical composition. Those aerosols that have no significant absorption in the UVB-visible spectral region (e.g. sulfate) act to scatter solar radiation, reducing the amount reaching the Earth's surface and resulting in an overall cooling effect. The cooling effect of anthropogenic sulfate aerosols in the Northern Hemisphere has been estimated to be comparable in magnitude to the atmospheric warming produced from increases in carbon dioxide $\left(\mathrm{CO}_{2}\right)$ (Kiel and Briegleb, 1993). Other aerosol species (e.g. black carbon) can both scatter and absorb solar radiation resulting in a cooling of the surface while simultaneously warming the atmosphere. Black carbon (BC) aerosols produced from incomplete combustion can reduce the amount of sunlight reaching the Earth's surface by as much as $10 \%$ (Ramanathan and Carmichael,

Published by Copernicus Publications on behalf of the European Geosciences Union. 
2008). However, they also increase the solar energy absorbed in the atmosphere by as much as $50 \%$ in some areas leading to heating of the particles and significant local warming of the boundary layer (Hermann and Hanel, 1997; Ramanathan and Carmichael, 2008). Absorbing aerosols may cause as much warming in the lower atmosphere as the major greenhouse gases, thus being a potentially important contributor to regional climate forcing (Ramanathan et al., 2007). The presence of absorbing aerosols in the troposphere can therefore result in a local heating of the air altering atmospheric stability and affecting large-scale circulation patterns and hydrologic cycles resulting in significant regional climate effects (Kaufman et al., 2002).

\subsection{Aerosol absorption}

The dominant light-absorbing aerosol species is thought to be $\mathrm{BC}$, commonly known as carbon soot, produced by incomplete combustion of fossil fuels and biomass burning. One of the largest sources of $\mathrm{BC}$ is emissions from diesel engines and therefore urban areas are thought to be one of the largest regional sources of absorbing aerosols dominated by $\mathrm{BC}$. The absorption of solar light by freshly emitted BC aerosols is broadband, decreasing monotonically with wavelength over the entire spectral region from UV to infrared (Marley et al., 2001).

Other light absorbing species are also present in atmospheric aerosols, including polycyclic and heterocyclic aromatic hydrocarbons and their nitrated derivatives (Jacobson, 1999), amino acids such as tryptophan in biological particles (Pinnick et al., 2004), and polycarboxylic acids known as "humic-like" substances (HULIS) (Cappiello et al., 2003). The polycyclic aromatic hydrocarbons (PAHs) are produced along with BC during combustion of fossil fuels and their nitrated derivatives are formed by atmospheric oxidation in the presence of $\mathrm{NO}_{2}$. The HULIS are produced from biomass burning (Hoffer et al., 2006), by atmospheric oxidation of BC (Decesari et al., 2002), or by atmospheric oxidation of biogenic hydrocarbons (Limbeck et al., 2003). These organic carbonaceous aerosol species have an enhanced absorption at shorter wavelengths $(<400 \mathrm{~nm})$ leading to aerosol absorption profiles greater than that expected from $\mathrm{BC}$ aerosols alone (Gelencsér et al., 2003).

The wavelength $(\lambda)$ dependence of aerosol absorption (A) is usually approximated by a power-law expression;

$A=\beta \lambda^{-\alpha}$

where $\alpha$ is the absorption Angstrom exponent (AAE) and $\beta$ is the aerosol absorption at $1 \mu \mathrm{m}$. The value of $\alpha$ depends on the chemical composition of the absorbing aerosol (Bergstrom et al., 2007). Freshly emitted BC particles from diesel engines have an AAE of 1 (Bergstrom et al., 2002; Marley et al., 2001) while carbonaceous aerosols produced from biomass burning have much stronger wavelength dependence of absorption, with an AAE of 2 (Kirchstetter et al., 2004). The water soluble HULIS isolated from biomass burning aerosols have very high AAEs in the range of 6 to 7 (Hoffer et al., 2006). Fine inorganic dust aerosols have been associated with a wide range of AAEs from values greater than 2 (Bergstrom et al., 2007) to less than 0.5 (Meloni et al., 2006) depending on their source and chemical composition.

An understanding of the wavelength dependence of aerosol absorption is important for several applications. An absorbing aerosol with an AAE of 3 will have an absorption coefficient in the UV that is 8 times larger than that in the visible (Bergstrom et al., 2007). This is not only important for the determination of the aerosol radiative forcing but also for atmospheric photochemical modeling. The $\mathrm{UV}$ is the most important spectral range for the promotion of atmospheric photochemical reactions. The presence of UV absorbing aerosols in the troposphere reduces the actinic flux throughout the boundary layer, which reduces the production of photochemical oxidants such as ozone and results in a buildup of the unreacted precursors in the atmosphere (Wendisch et al., 1996; Dickerson et al., 1997). The presence of absorbing aerosols in Mexico City leads to a reduction in the actinic flux below $430 \mathrm{~nm}$ by $10-30 \%$ (Castro et al., 2001). This reduction in UV radiation results in less surface level ozone produced in the city than would be expected from the precursor concentrations. The unreacted precursors are then transported out of the basin ultimately contributing to higher ozone levels in the surrounding region.

Aerosol absorption measurements have been used to determine $\mathrm{BC}$ aerosol mass concentrations by using the $\mathrm{BC}$ mass absorption efficiencies. Routinely the mass absorption efficiency is determined experimentally at one wavelength and an AAE of 1 is assumed to obtain the mass absorption efficiencies at other wavelengths (Hansen et al., 1984). This assumption can be a major source of error when comparing results of aerosol $\mathrm{BC}$ concentrations obtained from different methods. In a recent study, it was concluded that a better understanding of the wavelength dependence of aerosol absorption and how it varies with aerosol composition is needed in order to reconcile $\mathrm{BC}$ measurements made with different instrumental methods (Park et al., 2006).

The wavelength dependence of aerosol absorption has also been used to identify and classify different aerosol types (Meloni et al., 2006; Bergstrom et al., 2007). Remote sensing of aerosols by TOMS (Total Ozone Mapping Spectrometer) and OMI (Ozone Monitoring Instrument) type satellites utilizes the ratio of reflected light at two near-UVB wavelengths (e.g. 340 and $380 \mathrm{~nm}$ ) to determine the type of absorbing aerosols present in the atmosphere (Torres et al., 1998). Similar methods have been used to identify aerosols in ground-based studies. While urban aerosols that contain large concentrations of $\mathrm{BC}$ from the combustion of fossil fuels are associated with an AAE near 1 and aerosols impacted by biomass burning are associated with AAEs around 2, this can vary depending on the wavelength range used. In a recent study, biomass burning aerosols observed in South Africa 
yielded AAEs of 1.1 from $325-1685 \mathrm{~nm}$ and AAEs of 1.5 from 325-1000 nm (Bergstrom et al., 2007).

A thorough understanding of the wavelength dependence of aerosol absorption is therefore important for the estimation of aerosol radiative forcing as well as for the estimation of atmospheric photochemical oxidant production on local and regional scales. It is also important to the interpretation of satellite retrievals and the identification of absorbing aerosol sources and types, as well as for the comparison of aerosol $\mathrm{BC}$ concentration measurements made by different measurement methods. In addition, in order to predict aerosol absorption profiles over the atmospherically relevant spectral range, the measured aerosol absorption must be correlated to the type of absorbing aerosols present.

\subsection{Carbon isotopic tracers}

Carbon isotope measurements provide a powerful tool to identify different types of carbonaceous aerosols. Carbon-14 measurements can distinguish between fossil fuel and nonfossil fuel carbon sources. Carbon-14, produced naturally in the upper atmosphere by the interaction of nitrogen atoms with thermal neutrons, is taken up as ${ }^{14} \mathrm{CO}_{2}$ and enters the carbon cycle labeling all biogenic materials with a relatively constant initial ${ }^{14} \mathrm{C} /{ }^{12} \mathrm{C}$ ratio of about $1.5 \times 10^{-12}$ (Currie et al., 1982). Fossil fuels and the $\mathrm{BC}$ aerosols produced from their combustion contain no ${ }^{14} \mathrm{C}$ because their age (on the order of 100-200 million years) is much greater than the 5730year half-life of the radiocarbon. Therefore, the ${ }^{14} \mathrm{C}$ content in atmospheric aerosols, presented as the fraction of modern carbon (fM) provides a direct measure of the relative contributions of carbonaceous materials derived from fossil fuels and that derived from modern biomass sources.

Stable carbon isotope ratios are also useful for the identification of carbonaceous aerosol sources. Different plants can utilize two different photosynthetic pathways, denoted C-3 and C-4 according to the number of carbon atoms fixed by each pathway (Smith and Epstein, 1971). The difference in atomic masses of the three carbon isotopes, ${ }^{12} \mathrm{C}$, ${ }^{13} \mathrm{C}$, and ${ }^{14} \mathrm{C}$, affects the chemical reactivity and the physical processes sufficiently to cause selective uptake of ${ }^{12} \mathrm{CO}_{2}$ over both ${ }^{13} \mathrm{CO}_{2}$ and ${ }^{14} \mathrm{CO}_{2}$ during photosynthesis. The C3 plants, which utilize the Calvin-Benson photosynthetic cycle, have a more selective chemistry and fractionate the heavier carbon isotope $\left({ }^{13} \mathrm{C}\right)$ by about $12-14$ parts per thousand as compared to the less selective C-4 or Hatch-Slack photosynthetic pathway. The C-3 and C-4 plants will therefore be labeled with different ${ }^{13} \mathrm{C} /{ }^{12} \mathrm{C}$ ratios. The $\mathrm{C}-3$ plants are most abundant and comprise most tree species, shrubs, and cool temperate grasses and sedges, while the C-4 plants consist mostly of warm temperate to tropical grasses (Sage, 2001). The ${ }^{13} \mathrm{C} /{ }^{12} \mathrm{C}$ ratios $(R)$ are commonly expressed as $\delta^{13} \mathrm{C}$ values in per-mil $(\% o)$, and represent the difference between the measured $R$ and that of a carbon isotope standard, typically $\mathrm{CO}_{2}$ prepared from Peedee belemnite (PDB) carbonate. The measured ${ }^{13} \mathrm{C} /{ }^{12} \mathrm{C}$ ratios of organic matter are generally ${ }^{13} \mathrm{C}$ depleted compared to the $R$ of the PDB standard and are therefore reported as negative values. These resulting $\delta^{13} \mathrm{C}$ values are used to estimate the relative contributions from $\mathrm{C}$ $3\left(\delta^{13} \mathrm{C}=-27 \pm 6\right)$ and $\mathrm{C}-4\left(\delta^{13} \mathrm{C}=-13 \pm 4\right)$ (Boutton, 1991) plant sources to atmospheric carbonaceous aerosols.

\subsection{Mexico City field studies}

The Mexico City metropolitan area (MCMA) is the largest urban center in North America. Due to the high traffic densities and increased energy usage, Mexico City suffers from high levels of particulate $\mathrm{BC}$ pollution. The presence of highly absorbing aerosols in Mexico City has lead to a reduction in solar flux of $17.6 \%$ (Raga et al., 2001). The mass of absorbing aerosols exported from the MCMA into the surrounding region is estimated to be 6000 metric tons per day or 2 mega-tons per year (Gaffney et al., 1999). Since freshly formed combustion aerosols are hydrophobic, they are expected to be more resistant to washout and have longer lifetimes than more hygroscopic aerosols such as sulfate and nitrate (Gaffney and Marley, 2005; Dua et al., 1999). In addition, since Mexico City is at an altitude of $2250 \mathrm{~m}$ (7300 ft), these aerosols are released into the atmosphere at altitudes considered to be in the free troposphere elsewhere. The absorbing aerosols exported from the Mexico City basin are therefore assumed to have longer lifetimes than aerosols released at lower altitudes (Raga et al., 2001). Thus, the MCMA can be a major source of carbonaceous aerosols to the surrounding regions impacting the radiative balance and climate on a regional scale.

In order to better understand the sources of absorbing aerosols in the Mexico City basin and their impact on regional climate, the Mexico City 2003 field study was conducted in April of 2003, as part of the US Department of Energy's (USDOE) Atmospheric Science Program (ASP). This study was in collaboration with the Mexico City Metropoli$\tan$ Area 2003 (MCMA 2003) air quality study organized by M. J. Molina and L. T. Molina of the Massachusetts Institute of Technology. Aerosol absorption measurements were obtained as a function of wavelength at the Centro Nacional de Investigación y Capacitación Ambiental (CENICA), on the Iztapalapa campus of the Universidad Autónoma Metropolitana (UAM). In addition, fine mode $(<1$ micron) aerosol samples were collected every $12 \mathrm{~h}$ at the site.

In March 2006, a multiagency field campaign was undertaken in Mexico City called the Megacity Initiative: Local and Global Research Observations (MILAGRO). The MILAGRO study was composed of four collaborative field experiments, including the Megacity Aerosol Experiment, Mexico City 2006 (MAX-Mex) sponsored by the USDOE/ASP. The MAX-Mex field study was focused on the investigation of the direct radiative effect of aerosols in the Mexico City plume as a function of time, location, and processing conditions. Aerosol absorption measurements were obtained as a 
function of wavelength at the Instituto Mexicano del Petroleo (IMP), in the northwestern part of the MCMA. This site, known as T0, was chosen to represent the fresh emissions from the urban center. Fine mode aerosol samples were collected at site T0 and also at the Technological University of Tecamac, located $18 \mathrm{mi}$ northwest of T0. This second site, known as T1, was expected to represent a mixture of fresh and aged pollutants as they exit the basin.

Results are presented here for AAEs calculated from aerosol absorption measurements at seven wavelengths obtained by using a seven-channel aethalometer located in Mexico City during the two field campaigns in April 2003 and March 2006. These results are compared to AAEs calculated from continuous UV-visible absorption profiles obtained on the 12-h aerosol samples collected in the field. During both study periods substantial biomass burning events were observed, which were found to affect the aerosol absorption. The AAEs are compared to both stable and radiocarbon isotopic measurements made on the 12-h aerosol samples to evaluate the sources of carbon that give rise to the observed differences in aerosol absorption properties.

\section{Experimental methods}

\subsection{Sample sites}

Aerosol absorption measurements were obtained from 3 April 2003 (day 93) to 1 May 2003 (day 121) on the rooftop of the CENICA laboratory building $\left(19^{\circ} 21^{\prime} 44.541^{\prime \prime} \mathrm{N}\right.$, $99^{\circ} 04^{\prime} 16.425^{\prime \prime} \mathrm{W}$, elevation of $2247 \mathrm{~m}$ above sea level) on the Iztapalapa campus of the Universidad Autonóma Metropolitana (UAM). The UAM consists of 30 buildings on a campus of restricted traffic flow. It is located in the northeastern section of the MCMA in an area dominated by low cost housing and small industries.

Measurements of aerosol absorption were also obtained in 2006 from 10 March (day 69) to 29 March (day 88) at the Instituto Mexicano de Petroleo Laboratories (IMP). This site, known as T0, is located in the north central part of Mexico City (latitude $19^{\circ} 29^{\prime} \mathrm{N}$, longitude $99^{\circ} 09^{\prime} \mathrm{W}$, altitude of $2240 \mathrm{~m}$ a.s.l.) approximately $16 \mathrm{~km}(10 \mathrm{mi})$ north-northeast of the CENICA site. The IMP complex is a restricted campus of 33 buildings located in an industrial and commercial area of Mexico City surrounded by streets that are very heavily travelled by light duty vehicles and diesel busses. The nearest major roads are approximately $300 \mathrm{~m}$ away from the measurement site.

Aerosol samples were collected at both CENICA and IMP sites as well as at the Technological University of Tecamac, State of Mexico, (latitude $19^{\circ} 43^{\prime} \mathrm{N}$, longitude $98^{\circ} 58^{\prime} \mathrm{W}$, altitude 2340 m a.s.l.) from 1 March 2006 (day 60) to 29 March 2006 (day 88). This site, known as T1, was approximately $30 \mathrm{~km}(18 \mathrm{mi})$ north of Mexico City. The main transportation route through Tecamac is public road No. 85, which runs north-south from Mexico City to Pachuca. The municipality of Pachuca, located $94 \mathrm{~km}(58 \mathrm{mi})$ northeast of Mexico City and $64 \mathrm{~km}(40 \mathrm{mi})$ northeast of Tecamac, is also a potential source of emissions at site $\mathrm{T} 1$.

\subsection{Aerosol sampling}

Samples of fine mode $(<1.0$ micron) aerosols were collected at each site by using high volume samplers (Hi-Q Environmental Products, Model HVP-3800AFC) equipped with cascade impactors (Thermo Anderson). The samplers were equipped with brushless, three stage centrifugal fan blowers controlled by an electronic mass flow sensor that detects changes in the operator's pre-set flow rate caused by changes in temperature, barometric pressure, and pressure drop due to particulate loading on filter media. The high-volume sampler compensates for these changes by adjusting the motor speed to maintain the pre-set flow rate at 40 standard cubic feet per minute $(\mathrm{scfm})$. Three separate LCDs display elapsed time, total volume of air sampled, and instantaneous flow rate, which are recorded at the beginning and end of each sample interval.

The aerosol samples were collected on 8 in $\times 10$ in glass fiber filters (Whatman) in 2003 and 8 in $\times 10$ in quartz fiber filters (Pall Life Sciences) in 2006. The samples were taken at 12-h intervals from $05: 30$ to $17: 30$ and from 17:30 to 05:30 local standard time (LST). The volume of air sampled during the 12-h time period averaged $740 \mathrm{~m}^{3}$ with an average aerosol loading of $13 \mathrm{mg}$ total carbon content $\left(18 \mu \mathrm{g} / \mathrm{m}^{3}\right.$; $\left.\sigma=5 \mu \mathrm{g} / \mathrm{m}^{3}\right)$.

\subsection{Aerosol absorption measurements}

The absorption of fine aerosols was measured in the field by using a 7-wavelength aethalometer (Thermo-Andersen) with a sample inlet designed to collect aerosols in the size range of $0.1-2 \mu \mathrm{m}$ (Hermann et al., 2001). The aethalometer is currently the best method available for the measurement of aerosol AAEs in the field. This is the only instrument that allows for the measurement of aerosol absorption at more than 2 wavelengths and includes the UVB spectral range. Since most of the enhanced absorption occurs in the UVB range, instruments that only use visible wavelengths will underestimate the AAEs. However, the use of the aethalometer has been met with some controversy due to the inherent difficulties associated with the measurement of light attenuation by solid samples (Schmid et al., 2005; Arnott et al., 2005).

The aerosols in the sample air are collected within the aethalometer by continuous filtration through a paper tape strip. The optical attenuation of light transmitted through the particle laden filter is measured sequentially at seven wavelengths $(370,450,520,590,660,880$, and $950 \mathrm{~nm})$ by changing the LED sources. At low sample loadings, light scattering from the filter surface causes a reduction in intensity that is not associated with aerosol absorption, resulting in a 
positive error in the attenuation measurements. To reduce the occurrence of these light scattering artifacts, the instrument collects some sample onto the filter before taking measurements. As the sample is deposited on the paper tape strip, light attenuation increases steadily. At high sample loadings, high absorption values cause the instrument sensitivity to decrease. Therefore, the instrument automatically advances the tape to a new sample spot when light attenuation becomes severe.

Under normal operating conditions, the instrument calculates the $\mathrm{BC}$ concentration ([BC]) of the sample from the measured optical attenuation (ATN) by Eq. (2).

$\mathrm{ATN}=\sigma^{*}[\mathrm{BC}]$

The values for BC mass absorption efficiency $(\sigma)$ are determined from a previous comparison of aerosol light transmission measurements with thermal evolution methods, assuming a wavelength dependence of $\lambda^{-1}$ over the aethalometer's spectral range (Gundel et al., 1984; Hansen et al., 1982). Equation (2) also assumes that $\mathrm{BC}$ is the main absorbing aerosol species in the samples and that the sample path length is negligible and constant. Multiple scattering of light within the sample and filter substrate can cause an increase in path length, which changes as the filter becomes more heavily loaded with particles. In order to obtain quantitative measurements of aerosol $\mathrm{BC}$ concentrations from the light attenuation measurements, corrections must be made for these light scattering errors (Arnott et al., 2005). However, as long as these errors are not wavelength dependent, they will not be important in the calculation of aerosol AAEs.

The aethalometer results for $\mathrm{BC}$ aerosol concentrations $\left(\mu \mathrm{g} / \mathrm{m}^{3}\right)$ were converted to aerosol optical absorption $\left(\mathrm{m}^{-1}\right)$ at each wavelength by using the manufacturer's values for the mass absorption efficiencies. The calculated aerosol absorption measurements were recorded at five-minute intervals for each of the seven wavelengths. Measurements obtained just prior to and immediately after the filter tape advance were discarded as outliers (Arnott et al., 2005). The AAEs were calculated from one-hour averages of the five minute optical absorption measurements at the seven wavelengths by a least squares fit to Eq. (3).

$$
\ln (\mathrm{A})=-\alpha \ln \lambda+\ln \beta
$$

The correlation coefficient $\left(r^{2}\right)$ obtained from the least squares fit serves as a measure of the assumption that the wavelength dependence of the aerosol absorption follows the exponential relationship in Eq. (1). The correlation coefficients from these calculations varied from 0.9999 to 0.96 with a standard deviation of 0.004 in 2003 and from 0.9997 to 0.95 with a standard deviation of 0.006 in 2006, indicating that the AAE is a good representation of the wavelength dependence of the aerosol absorption for the majority of measurements.
Aerosol absorption profiles were also obtained in the laboratory on the 12-h aerosol samples collected at each site (Marley et al., 2001). Spectra were recorded from 850 to $280 \mathrm{~nm}$ at a spectral resolution of $1.6 \mathrm{~nm}$ with a research grade UV-visible-NIR spectrometer (Perkin Elmer, Lambda 1050) equipped with an integration sphere reflectance accessory (Labsphere) developed specifically for the analysis of solid samples. Aerosol AAEs were calculated from the diffuse reflectance spectra by a least squares fit to Eq. (3) using all 350 points.

The integration sphere is designed to collect all the light scattered by the surface of the sample and direct it back to the detector (Marley et al., 2001). Therefore, all light scattered from the sample surface is measured by the detector and any reduction in intensity is due to sample absorption only. The interior of the sphere is coated with a perfectly diffuse reflectance coating (Spectralon $®$ ) and the detector view is limited to incident flux that has undergone at least two reflections from the sphere surface. This assures that the incident beam undergoes multiple reflections in the interior of the sphere increasing the sensitivity of the technique.

The relationship between absorbance and the diffuse reflectance is described by the Kubelka-Munk function, $F(R)$ as

$F(R)=\left(1-R^{2}\right) / 2 R=k / s$

where $R$ is the intensity of light reflected from the sample, $k$ is the Kubelka-Munk absorption coefficient and $s$ is the sample scattering coefficient. The sample scattering coefficient is related to the real refractive index $(n)$ of the bulk material, which is not significantly wavelength dependent (Marley et al., 2001). The wavelength dependence of $F(R)$ is therefore a direct measure of the wavelength dependence of the sample absorption. In addition, $F(R)$ is not dependent on the sample path length as in transmission spectroscopy. Therefore, multiple reflections within the filter do not present a source of error in reflection spectroscopy and can be neglected.

The AAEs calculated from the 7 wavelengths measured by the aethalometer in the field were averaged over the same 12$\mathrm{h}$ time period used for the sample collection. A comparison between the AAEs calculated from the 7 wavelengths of the aethalometer and those calculated from the full diffuse reflectance spectrum (350 points) obtained in the laboratory on the filter samples is shown in Fig. 1. This comparison gives a correlation coefficient of 0.62 with a slope of 0.67 and an intercept of 0.3. A major source of error in this comparison is that the aethalometer values are averaged over a $12 \mathrm{~h}$ period whereas the diffuse reflectance is obtained on a 12-h composite sample. Since the samples deposited on the filters are optically thick, the spectra obtained from them will be heavily weighted by the sample deposited in the last hours of sampling and will not represent a true average of the 12-h time period. The linear fit shown in Fig. 1 is determined from comparing the AEAs calculated from all 350 points in the full diffuse reflectance spectrum with the AAEs calculated 


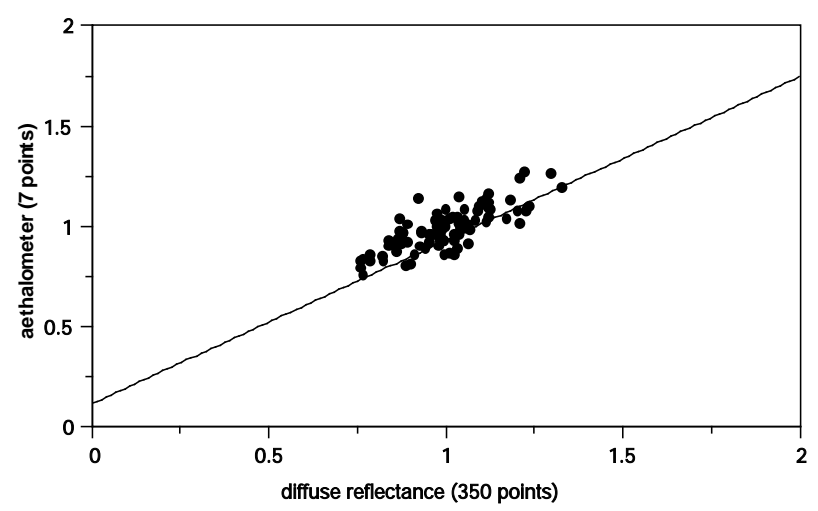

Fig. 1. Comparison between aerosol absorption Ångstrom exponents calculated from aerosol absorption measured at 7 wavelengths with an aethalometer and absorption measured by diffuse reflectance at 350 wavelengths between $280-850 \mathrm{~nm}$. The reported linear fit is for diffuse reflectance calculated from the same wavelengths used by the aethalometer.

using only the 6 wavelengths that correspond to those used by the aethalometer $(370,450,520,590,660$, and $880 \mathrm{~nm})$. This comparison yields a correlation coefficient of 0.86 with a slope of 0.82 and an intercept of 0.2 and represents the errors introduced in the calculation of the AAEs by using a small set of wavelengths.

\subsection{Carbon measurements}

The aerosol samples collected in 2003 were oxidized to $\mathrm{CO}_{2}$ by using a low-temperature oxygen plasma (Rowe and Steelman, 2002). A custom-built plasma oxidation apparatus allowed for collection of $\mathrm{CO}_{2}$ in a glass sample tube. A glow discharge was produced by radio frequency (RF) capacitive coupling with two external copper electrodes on either end of a $12 \mathrm{~cm} \times 4.6 \mathrm{~cm}$ glass sample chamber. Vacuum conditions were maintained with a turbomolecular pump and a diaphragm fore pump. Successive oxygen plasmas (1 torr; $100 \mathrm{~W}$ ) were used to clean the empty sample chamber until less than $1 \mu \mathrm{g}$ of carbon remained. Approximately $60 \mathrm{~cm}^{2}$ of the aerosol filter sample was inserted into the sample chamber under a positive pressure to prevent the introduction of atmospheric $\mathrm{CO}_{2}$ or particulates. A one-hour argon plasma (1 torr; $40 \mathrm{~W}$ ) was used to remove adsorbed gases followed by a one-hour oxygen plasma ( 1 torr; $100 \mathrm{~W}$ ), which converted the carbonaceous material on the filter to $\mathrm{CO}_{2}$ and $\mathrm{H}_{2} \mathrm{O}$. A second oxygen plasma was performed to ensure quantitative transfer of carbon from the filter.

The samples collected in 2006 were converted to $\mathrm{CO}_{2}$ by thermal combustion. Each sample was sealed under vacuum in a quartz tube with copper oxide, metallic copper and silver and combusted at $900^{\circ} \mathrm{C}$. The $\mathrm{CO}_{2}$ produced from the combustion was cryogenically isolated from other combustion products and the amount was measured manometrically.
The $\mathrm{CO}_{2}$ collected from the aerosol samples was converted to graphite by hydrogen reduction using an iron catalyst. The resulting graphitic carbon was then pounded into an $\mathrm{Al}$ target and the ${ }^{14} \mathrm{C} /{ }^{12} \mathrm{C}$ ratios were measured by accelerator mass spectrometry (AMS) at the Center for Accelerator Mass Spectrometry (CAMS) at Lawrence Livermore National Laboratory (LLNL). The results are reported as the fraction of modern carbon (fM) in the total carbon of the aerosol sample (Stuiver and Polach, 1977).

Samples of $\mathrm{CO}_{2}$ were also isolated by thermal combustion of the aerosol samples for the determination of ${ }^{13} \mathrm{C}$ content by stable isotope ratio mass spectrometry. Isotope ratio measurements of $\mathrm{CO}_{2}$ were made using an Elemental Analyzer (Carlo Erba NCS 2500) coupled to a triple-collector gas source mass spectrometer (Thermo Finnigan Delta Plus XL). Two l-glutamic acid references (USGS-40; $\delta^{13} \mathrm{C}=-26.39$ and USGS-41; $\left.\delta{ }^{13} \mathrm{C}=+37.63\right)$ were analyzed concurrently with the samples. All references were matrix matched to the aerosol samples by the addition of blank quartz filters. Vanadium pentoxide was added to all references and samples to ensure complete combustion in the elemental analyzer. Masses 44,45 , and $46\left(\mathrm{CO}_{2}+\right.$ ions $)$ were measured in the samples and standard gases. Isotope ratios were calculated by comparison with those in the reference $\mathrm{CO}_{2}$ samples calibrated to the Solenhofen Limestone standard (NBS20), which had a ${ }^{13} \mathrm{C} /{ }^{12} \mathrm{C}$ ratio of 0.0112253 (Craig, 1957). The results are reported in conventional delta $(\delta)$ notation described by

$\delta^{13} \mathrm{C}=\left[\left(R_{\text {sample }} / R_{\text {standard }}\right)-1\right] \times 1000$

where $R$ is the atom ratio ${ }^{13} \mathrm{C} /{ }^{12} \mathrm{C}$ expressed in units of permil $(\% o)$ deviation relative to the isotopic reference material standard (VPDB) for which $\delta^{13} \mathrm{C}$ is defined as $0.00 \%$ (Coplin et al., 2006). The analytical uncertainty of the $\delta^{13} \mathrm{C}$ values reported here is $\pm 0.3 \%$ o.

\section{Results and discussion}

\subsection{Aerosol absorption}

The aerosol AAEs calculated from the aethalometer absorption measurements made in Mexico City in April 2003 and March 2006 are shown in Fig. 2. In 2003 the AAEs varied from 0.76 to 1.5 with an overall average of 1.05 . The AAEs determined at site T0 in 2006 were slightly lower with a range of 0.63 to 1.4 and an average of 0.94 . Figure 3 shows the AAEs averaged over the morning (06:00-12:00LST) and afternoon (12:00-18:00 LST) hours for April 2003 and March 2006. For the majority of days during both studies, the afternoon AAEs were higher than the morning values. The difference between morning and afternoon AAEs in 2003 ranged from 0.08 to 0.29 with an average of 0.14 , excluding day 99 . The afternoon of day 99 was dominated by a particularly turbulent thunderstorm (see Fig. 4) that lofted fine 

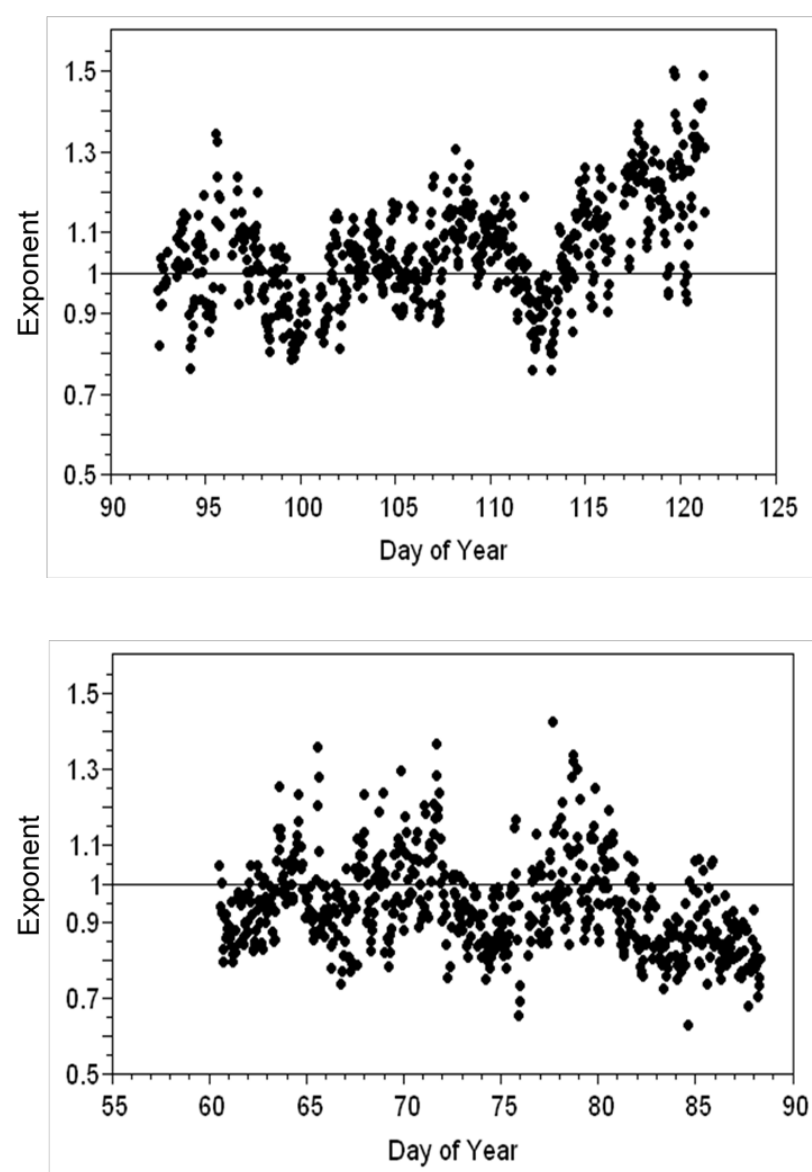

Fig. 2. Aerosol absorption Ångstrom exponents calculated from aerosol absorption measured at 7 wavelengths in Mexico City during April 2003 (top) and March 2006 (bottom).

dust, accompanied by heavy cloud cover that significantly reduced solar radiation in Mexico City during the day. Fine dust aerosols have been associated with low AAEs (Meloni et al., 2006). In addition, the reduced solar flux caused by increased cloud cover would result in decreased photochemistry and a decreased production of oxidized aerosol species (Tang et al., 2003). This resulted in the afternoon average AAE being lower than the morning average AAE for day 99 .

The last week of March 2006 (after day 82) was again dominated by heavy thunderstorms accompanied by large amounts of dust lofting and heavy cloud cover (see Fig. 4). This resulted in AAEs during this period that were lower than the rest of the study period in 2006 and were also essentially the same for both morning and afternoon hours. During the remaining study period (excluding the days 82 through 88 ) the difference between morning and afternoon AAEs ranged from 0.06 to 0.22 with an average of 0.13 , resembling the results obtained in 2003.

A rapid photochemical production of secondary organic aerosols (SOA) has been observed in the Mexico City area primarily in the morning hours beginning at 08:00 (Salcedo
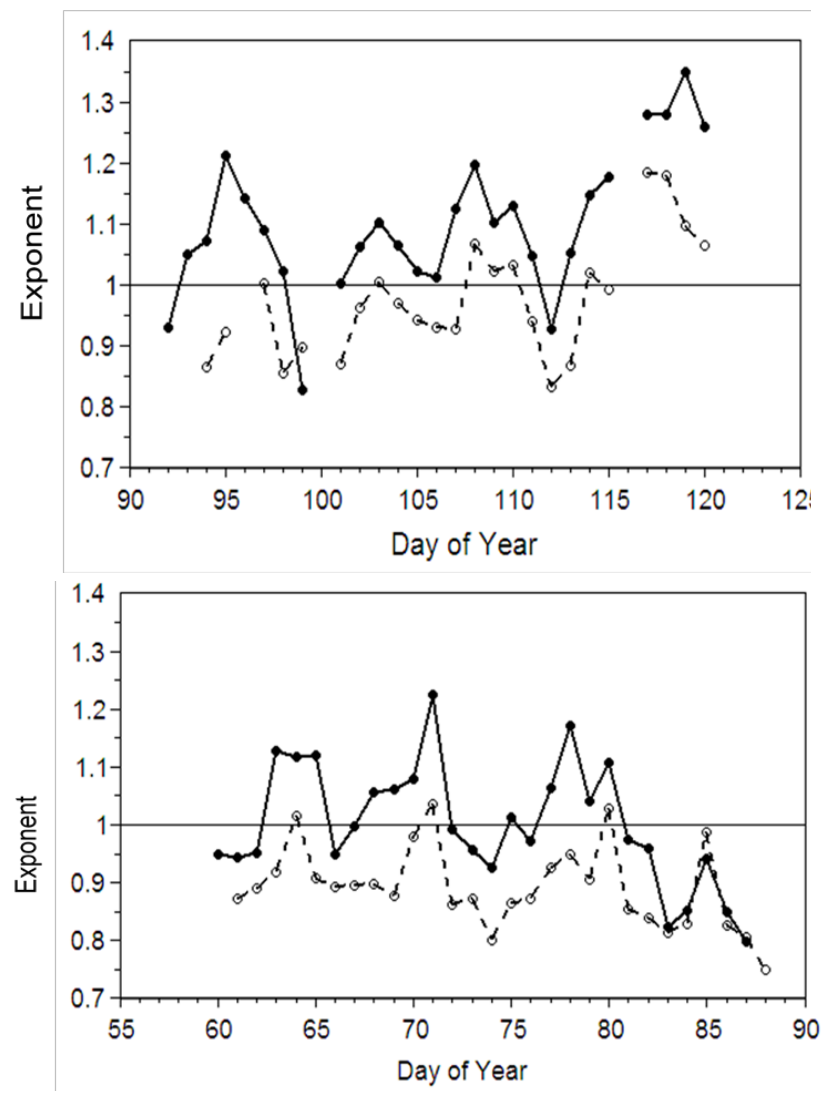

Fig. 3. Aerosol absorption Ångstrom exponents calculated for morning (o) and afternoon (•) hours in Mexico City during April 2003 (top) and March 2006 (bottom).

et al., 2006; Hennigan et al., 2008; Aiken et al., 2008; Volkamer et al., 2006; Paredes-Miranda et al., 2008). Thus, the increase in aerosol AAEs in the afternoons cannot be explained by the formation of SOA alone. This increase in AAEs in the afternoon hours is therefore most likely due to the photochemical aging of preexisting aerosols leading to more highly UV absorbing oxidized organic species such as HULIS, resulting in higher AAEs than observed from either the fresh primary emissions or SOA formation in the morning (Mang et al., 2008; Walser et al., 2007; Decesari et al., 2002).

The values of the AAEs averaged over the nighttime hours (18:00-06:00 LST) were consistently intermediate between morning and afternoon values during both field studies. This is due to a combination of the venting of the aged pollutants in the basin at night (de Foy et al., 2006) and fresh evening emissions replacing them. The resulting nighttime aerosols remaining in the basin are a mixture of some photochemically aged aerosols from the previous afternoon and freshly emitted aerosols at night yielding AAEs that fall between those typical of fresh emissions observed in the mornings and those of photochemically aged aerosols observed in the afternoons. 

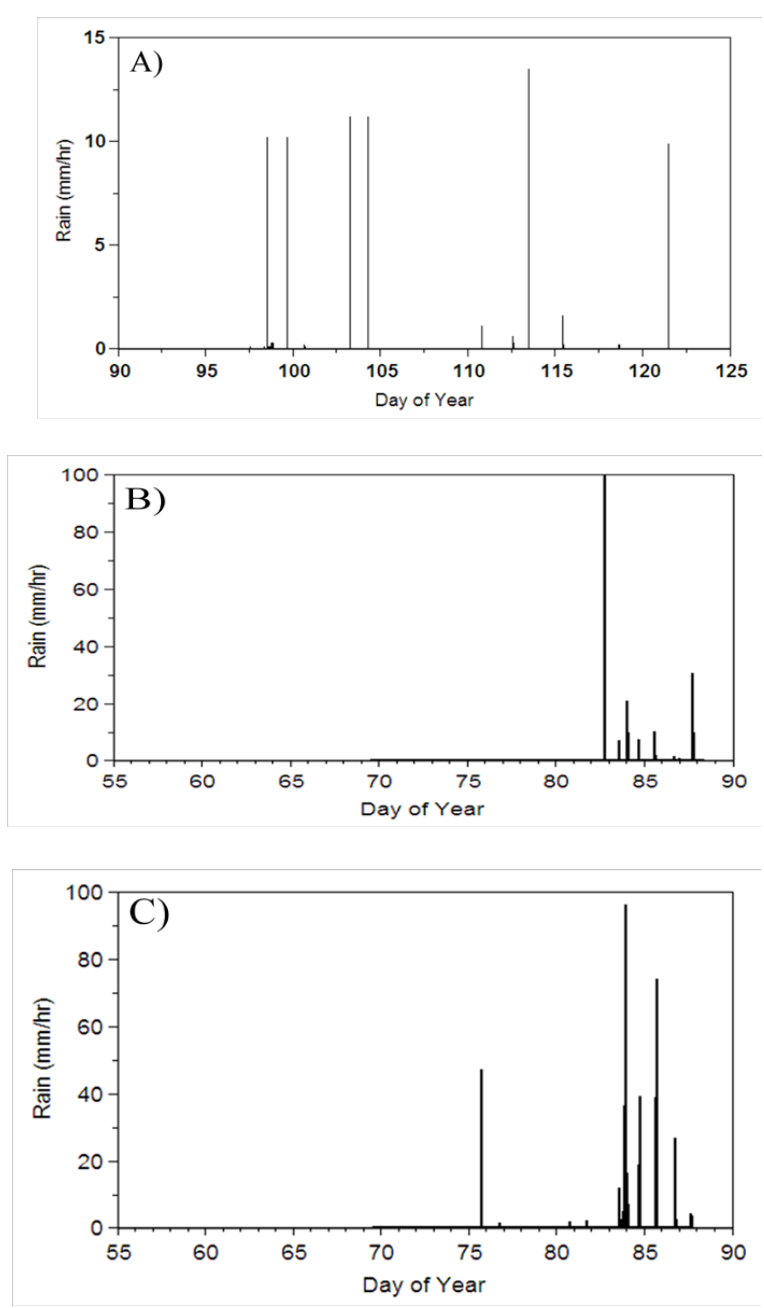

Fig. 4. Rain intensity (mm/hr) measured at CENICA in April 2003 (A) and at sites T0 (B) and T1 (C) in March 2006.

The highest AAEs were observed in 2003 during the last week of April (days 116 to 120), with hourly averages ranging from 0.9 to 1.6 and an overall average of 1.2 (see Fig. 2). Satellite data has shown that smoke plumes from widespread Yucatan fires in 2003 heavily impacted the Valley of Mexico during the entire month of April. The most direct impacts on Mexico City occurred during the last week of April (Massie et al., 2006). Although both deforestation and crop residue fires are common in the Yucatan (Yokelson, 2009), the emissions from fires in 2003 were particularly intense. True-color satellite images clearly show smoke plumes that originated from the Mexico-Guatemala border impacting Mexico City on April 18 (day 108), which was also a period of the high AAEs (Massie et al., 2006). These results agree with previous studies that show aerosols associated with biomass burning typically have higher AAEs than aerosols produced by the combustion of fossil fuels (Hoffer et al., 2006; Kirchstetter et al., 2004).
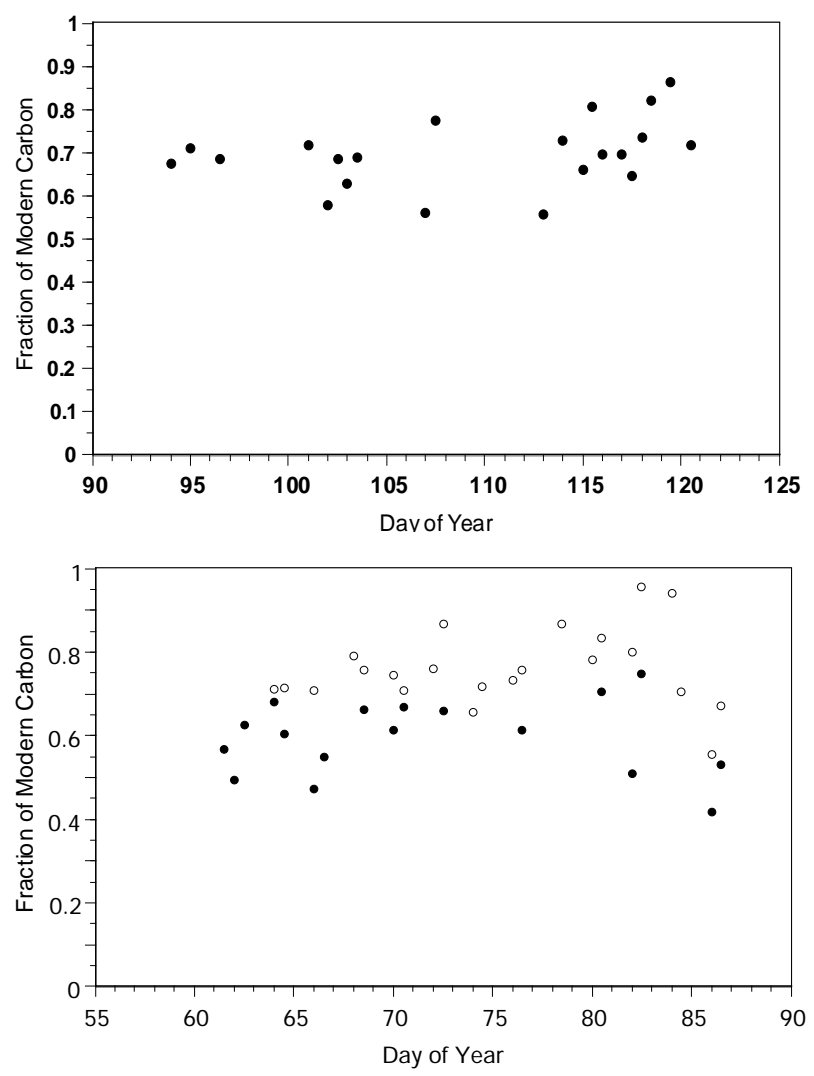

Fig. 5. Fraction of modern carbon in fine aerosol samples collected at CENICA in Mexico City in April 2003 (top) and at sites T0 (•) and T1 in (o) March 2006 (bottom).

\subsection{Carbon-14 measurements}

The fM values measured in the fine aerosol samples collected in Mexico City are shown in Fig. 5. At the CENICA site in April 2003, the fM ranged from 0.56 to 0.86 with an average of 0.70. The fM in samples collected in March 2006 ranged from 0.42 to 0.75 with an average of 0.60 at site T0 and from 0.55 to 0.96 with an average of 0.76 at site $\mathrm{T} 1$. Overall, the carbonaceous aerosols produced in the Mexico City basin consisted of approximately $70 \%$ biogenic materials. These biogenic aerosol components can be derived either from biomass burning or from SOA formation from biogenic precursors.

Other studies conducted in the Mexico City area during either MCMA2003 or MILAGRO have found evidence of large impacts from biomass burning during both campaigns (Yokelson et al., 2007, 2009; Johnson et al., 2006; Moffet et al., 2008; DeCarlo et al., 2008; Stone et al., 2008). Aircraft studies in the Yucatan estimated that approximately $44 \mathrm{Tg}$ of biomass was burned in the Yucatan in the spring of 2006 from both forest and crop clearing (Yokelson et al., 2009). Measurements of particulate to $\mathrm{CO}$ ratios suggested that as much as $79-92 \%$ of the primary fine particulate mass in the Mexico 
Table 1. Fraction of modern carbon (fM) reported for some urban areas.

\begin{tabular}{lccccc}
\hline Site & Sample & Season & Year & fM Average (Range) & Reference \\
\hline Los Angeles, Ca & $\mathrm{PM}_{10}$ & $\mathrm{~S}$ & 82 & 0.31 & Hildemann \\
Los Angeles, Ca & $\mathrm{PM}_{10}$ & $\mathrm{~W}$ & 82 & 0.41 & Hildemann \\
Long Beach, Ca & $\mathrm{PM}_{10}$ & $\mathrm{~S}$ & 82 & 0.49 & Hildemann \\
Long Beach, Ca & $\mathrm{PM}_{10}$ & $\mathrm{~W}$ & 82 & 0.47 & Hildemann \\
Denver, Co & $\mathrm{PM}_{2.5}$ & $\mathrm{~S}$ & 96 & $0.44(0.09-0.70)$ & Klinedinst \\
Denver, Co & $\mathrm{PM}_{2.5}$ & $\mathrm{~W}$ & $96-97$ & $0.27(0.13-0.72)$ & Klinedinst \\
Nashville, Tn & $\mathrm{PM}_{2.5}$ & $\mathrm{~S}$ & 99 & $0.69(0.56-0.80)$ & Lewis \\
Houston, Tx & $\mathrm{PM}_{2.5}$ & $\mathrm{~S}$ & 00 & $0.54(0.27-0.77)$ & Allen \\
Tampa, Fl & $\mathrm{PM}_{2.5}$ & $\mathrm{~S}$ & 02 & $0.75(0.55-0.95)$ & Lewis and Stiles \\
Zurich, Ch & $\mathrm{PM}_{2.5}$ & $\mathrm{~S}$ & 02 & $0.63(0.60-0.67)$ & Szidat \\
Launceston, Au & $\mathrm{PM}_{10}$ & $\mathrm{~W}$ & $03-04$ & $0.95(0.86-1.0)$ & Jordan \\
Seattle, Wa & $\mathrm{PM}_{2.5}$ & $\mathrm{~S}$ & 04 & $0.55(0.38-0.64)$ & Bench \\
Seattle, Wa & $\mathrm{PM}_{2.5}$ & $\mathrm{~W}$ & $04-05$ & $0.58(0.46-0.69)$ & Bench \\
Tokyo, Jp & $\mathrm{PM}_{2.1}$ & $\mathrm{~S}$ & 04 & $0.38(0.31-0.50)$ & Takahashi \\
Tokyo, Jp & $\mathrm{PM}_{2.1}$ & $\mathrm{~W}$ & $04-05$ & $0.47(0.41-0.54)$ & Takahashi \\
Phoenix, Az & $\mathrm{PM}_{2.5}$ & $\mathrm{~S}$ & 05 & $0.60(0.49-0.75)$ & Bench \\
Phoenix, Az & $\mathrm{PM}_{2.5}$ & W & $05-06$ & $0.53(0.49-0.59)$ & Bench \\
\hline
\end{tabular}

Note: $\mathrm{PM}_{2.1}$ is particulate matter less than 2.1 microns, $\mathrm{PM}_{2.5}$ is particulate matter less than 2.5 microns, $\mathrm{PM}_{10}$ is particulate matter less than 10 microns. $\mathrm{S}$ is summer, $\mathrm{W}$ is winter.

City area could be produced by pine forest fires in the surrounding mountain areas (Yokelson et al., 2007). Studies of marker compounds estimated that the biomass burning contribution to organic aerosol components varied from 5-26\% at $\mathrm{T} 0$ and from $7-39 \%$ at $\mathrm{T} 1$ during the study period (Stone et al., 2008), while studies using aerosol mass spectrometry found indications that aerosols from biomass burning comprised $40 \%$ of the submicron aerosols at $\mathrm{T} 0$.

The reported values of $\mathrm{fM}$ for some other urban areas are listed in Table 1. Early measurements made in Los Angeles and Denver previous to the year 2000 resulted in lower $\mathrm{fM}$ values reflecting a higher percentage of fossil fuel derived materials (Hildeman et al., 1994; Klinedinst and Currie, 1999). The major sources in the Los Angeles area at this time were estimated to be meat cooking operations (17\%), diesel vehicles (14\%), paved road dust (14\%), fireplaces (12\%), and non-catalyst equipped gasoline vehicles (11\%). It is also interesting to note that $\mathrm{fM}$ values for arctic haze carbonaceous aerosols in the early 1980s were found to be in the range of 0.3 to 0.4 (Gaffney et al., 1984). More recent measurements in the US have resulted in larger $\mathrm{fM}$ values reflecting a lower percentage of fossil-derived absorbing carbon. This is possibly a result of implementing tighter controls on motor vehicle emissions and the addition of biofuels throughout the US (Gaffney and Marley, 2000) compounded by little control of open burning.

The very high $\mathrm{fM}$ values reported for Launceston, Tasmania in Table 1 were attributed to residential wood burning in the wintertime with $1 / 3$ of households using wood heaters or open fireplaces (Jordan et al., 2006). The high fM values ob- served in Nashville and Tampa during the summertime were attributed to secondary organic aerosol formation (Lewis and Stiles, 2006; Lewis et al., 2004).

The fM values measured at site T0 in 2006 (average of 0.6) were generally lower than those measured in Mexico City in 2003 (average of 0.7) and this also correlates well with the higher AAEs obtained for 2003. This is likely due to the larger impact of biomass burning in 2003 from the Yucatan fires. In addition, the fM values measured at site T1 in 2006 (average of 0.76) was generally higher than that measured at either site T0 in 2006 or at CENICA in 2003. Site T1 was heavily impacted by local grass fires during most of the study period contributing to the higher $\mathrm{fM}$ values in the aerosol samples. The $\mathrm{fM}$ values measured at site $\mathrm{T} 1$ during the last few days of 2006 were lower than those during the rest of the study period due to heavy rains that extinguished the local fires thus reducing the biomass input to the aerosol carbon.

The AAEs obtained by diffuse reflectance on the aerosol samples were compared to the $\mathrm{fM}$ value on each sample. The correlation between the $\mathrm{fM}$ values and the AAEs of the Mexico City aerosols is shown in Fig. 6. In general, those samples that have high $\mathrm{fM}$ values also show higher AAEs. The results obtained at site T0 in 2006 are most consistent with fresh carbon emissions (AAE closest to 1). Those for 2003 are somewhat higher and consistent with a mixture of fresh urban emissions and aged biomass emissions. The three highest points shown in Fig. 6 for 2003 were obtained during the last week of the study period when Mexico City was impacted most directly by aged biomass burning aerosols from the fires in the Yucatan (Massie et al., 2006). The results for site T1 


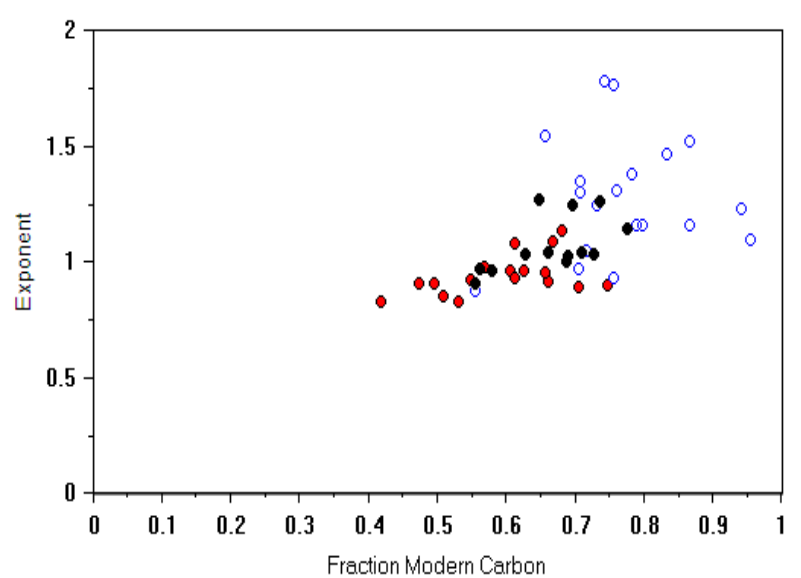

Fig. 6. Aerosol absorption Ångstrom exponents as a function of the fraction of modern carbon determined in Mexico City during April 2003 (black) and March 2006 at site T0 (red) and at site T1 (blue).

in 2006 are highest and more typical of a larger impact of the low temperature grass fires in the area.

\section{$3.3{ }^{13} \mathrm{C} /{ }^{12} \mathrm{C}$ Ratios}

The $\delta^{13} \mathrm{C}$ values of the aerosol samples collected in Mexico City in 2003 ranged from -22 to $-30 \%$ with an average of $-26 \%$; while those measured at site T0 in 2006 were similar, ranging from -23 to $-28 \%$ with an average of $-25 \%$ o (see Fig. 7). These values are in the range of biogenic material from trees, shrubs and other C- 3 plants. The $\delta^{13} \mathrm{C}$ of the fine aerosol samples collected at T1 in 2006 were somewhat higher, ranging from -15 to $-27 \%$ with an average of $-23 \%$ indicating a mixture of biogenic materials from C3 trees and shrubs with significant input from the C-4 grass fires in the area.

The relationship between the $\delta^{13} \mathrm{C}$ and $\mathrm{fM}$ values of the aerosol samples is shown in Fig. 8. The samples from site T1 in 2006 are generally higher in both $\delta^{13} \mathrm{C}$ and $\mathrm{fM}$ than the samples collected at site $\mathrm{T} 0$, again indicating the influence of local grass fires in the vicinity of site T1. While the fM values of the aerosol samples collected in 2003 are closer to those from site $\mathrm{T} 0$ than those from site $\mathrm{T} 1 \mathrm{in} 2006$, the $\delta^{13} \mathrm{C}$ values were lower at $\mathrm{T} 0$ in 2006. This is another indication of input from the Yucatan fires in 2003, which were C-3 forest fires that would result in lower $\delta^{13} \mathrm{C}$ values.

\section{Conclusions}

The results of this study clearly indicate that there can be substantial differences in the AAEs of atmospheric carbonaceous aerosols and that these differences can be correlated to the sources of the carbon. While carbonaceous aerosols produced from the combustion of fossil fuels have Ångstrom coefficients near 1 (Bergstrom et al., 2002), this work
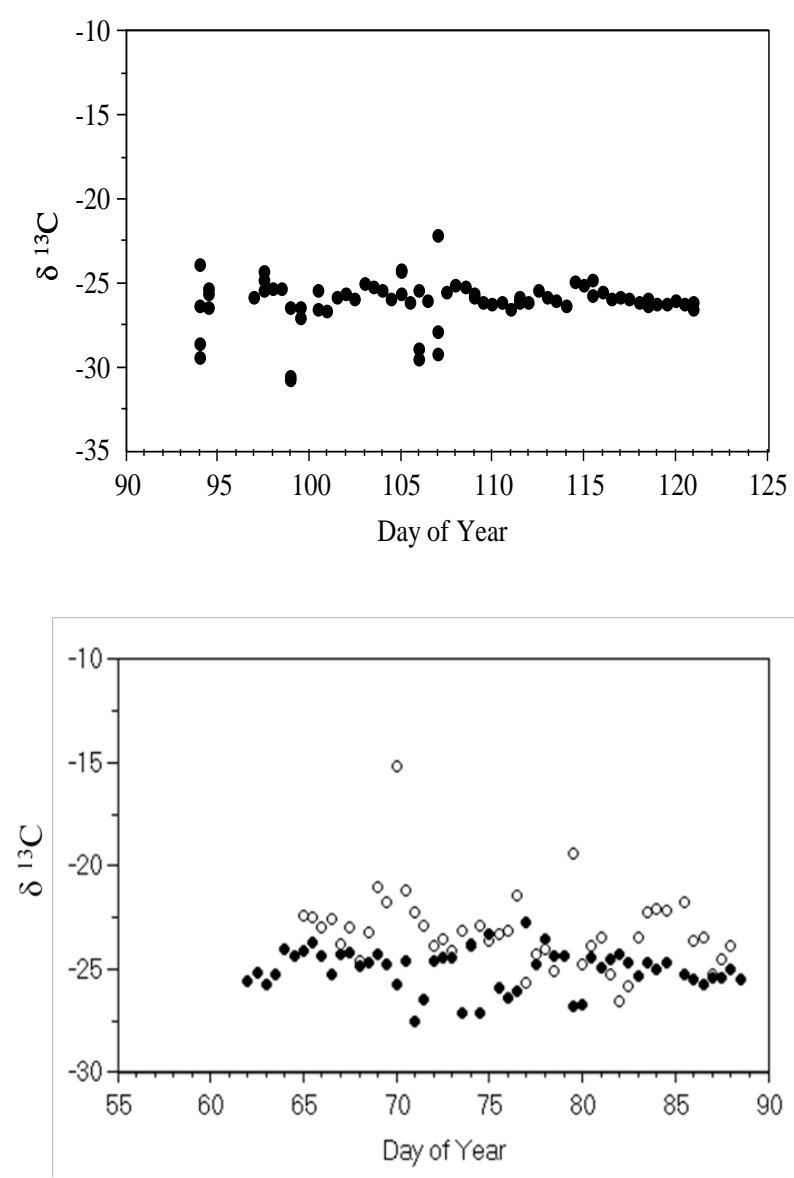

Fig. 7. Carbon-13 content in fine aerosol samples collected at CENICA in Mexico City in April 2003 (top) and at sites T0 (•) and $\mathrm{T} 1$ (o) in March 2006 (bottom) expressed as the ratio of ${ }^{13} C /{ }^{12} \mathrm{C}$ $\left(\delta^{13} \mathrm{C}\right)$ in units of per-mil $(\% o)$ deviation relative to the standard reference VPDB.

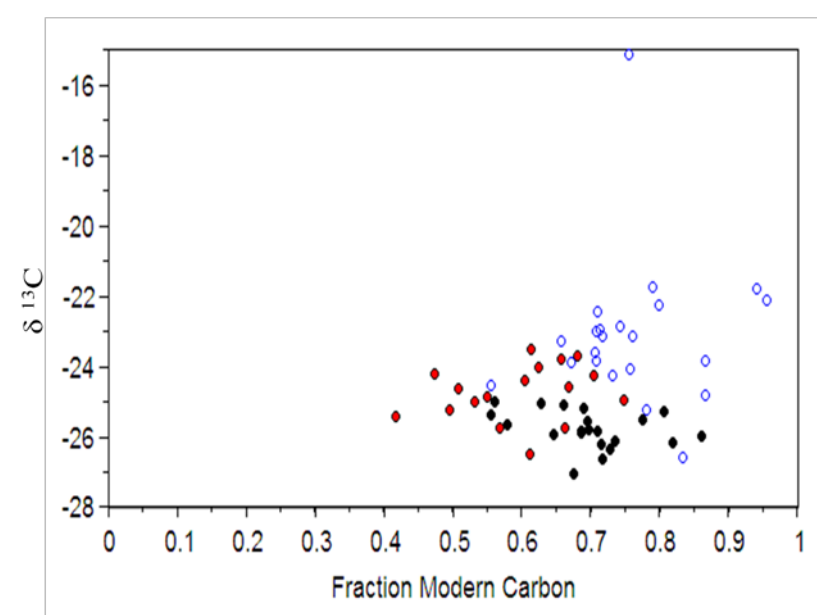

Fig. 8. Carbon- 13 content $\left(\delta^{13} \mathrm{C}\right)$ in fine aerosol samples as a function of the fraction of modern carbon (fM). Samples were collected at CENICA in Mexico City in April 2003 (black) and at sites T0 (red) and T1 (blue) in March 2006. 
clearly demonstrates significant variations in the absorption of UVB-Visible radiation for carbonaceous aerosols derived from biogenic sources such as biomass burning events. This is consistent with the fact that the organic aerosol components derived from these sources have significant amounts of partially oxidized functional groups present in the molecules. These include chromophores such as conjugated carbonyls, oxidized and nitrated PAH derivatives, and other molecular structures that serve to enhance absorption in the UVB leading to changes in the observed AAEs from the expected value of about 1 to values ranging from 0.75 to 2.8 . This variation has been found to correlate with biomass burning as indicated from both stable carbon isotope ratios and radiocarbon activities.

The radiocarbon results clearly indicate a significant impact from modern carbon aerosol sources, even in the urban area, and these aerosols have absorption properties much different than those derived from fossil fuel combustion. These biomass sources could include both grass and forest fires as well as trash-burning in the megacity environment. Two types of biomass burning events that occurred during the 2003 and 2006 studies allowed for the impact of biomass burning on aerosol AAEs to be examined. These results show that low temperature grassfires, such as those that occurred near site T1 in 2006, will result in aerosols with significantly higher AAEs than the high temperature and more remote forest fires that impacted Mexico City in 2003.

The variance observed in the AAEs clearly needs to be taken into account in areas where significant biomass burning occurs as well as in areas where photochemical aerosol aging occurs, such as in megacity environments and downwind of these areas. This is important not only for the determination of aerosol radiative impacts but also for the interpretation of remote sensing of absorbing aerosols by satellites such as TOMS or OMI as well as in reconciling the results of $\mathrm{BC}$ mass measurements obtained by different methods.

Acknowledgements. This work was conducted as part of the Department of Energy's Atmospheric Science Program and was supported by the Office of Science (BER), US Department of Energy Grants No. DE-FG02-07ER64328 and No. DE-FG02-07ER64329. We wish to thank Mr. Rick Petty and Ashley Willamson of OBER for their continuing encouragement. We also wish to thank Mexican Scientists and students for their assistance from the Instituto Mexicano de Petroleo (IMP) and CENICA in helping to collect aerosol samples for carbon isotopic analyses.

Edited by: L. Molina

\section{References}

Aiken, A. C., DeCarlo, P. F., Kroll, J. H., Worsnop, D. R., Huffman, J. A., Docherty, K. S., Ulbrich, I. M., Mohr, C. Kimmel, J. R., Sueper, D., Sun, Y., Zhang, Q., Trimborn, A., Northway,
M., Zieman, P. J., Canagaratna, M. B., Onash, T. B., Alfarra, M. R., Prevot, A. S. H., Dommen, J., Duplissy, J., Metzger, A., Baltensperger, U., and Jimenez, J. L.: O/C and M/OC ratios of primary, secondary, and ambient organic aerosols with high resolution time-of-flight aerosol mass spectrometry, Environ. Sci. Technol., 42, 4478-4485, 2008.

Allen, D.: Gulf Coast Aerosol Research and Characterization Program (Houston Supersite), Progress Report, August 2001, Environmental Protection Agency Technology Transfer Network Ambient Monitoring Technology Information Center, Houston Supersite Project Information, online available at: http://www. epa.gov/ttnamti1/houprog.html, last access: 20 February 2009, 2001.

Arnott, W. P., Hamasha, K., Moosmuller, H., Sheridan, P. J., and Ogren, J. A.: Towards Aerosol Light-Absorption Measurements with a 7-Wavelength Aethalometer: Evaluation with a Photoacoustic Instrument and 3-Wavelength Nephelometer, Aerosol Sci. Technol., 39, 17-29, 2005.

Bench, G., Fallon, S., Schichtel, B., Malm, W., and McDade, C.: Relative contributions of fossil and contemporary carbon sources to $\mathrm{PM}_{2.5}$ aerosols at nine Interagency Monitoring for Protection of Visual Environments (IMPROVE) network sites, J. Geophys. Res., 112, D10205, doi:10.1029/2006JD0077082007, 2007.

Bergstrom, R. W., Russell, P. B., and Hignett, P. B.: The wavelength dependence of black carbon particles: Predictions and results from TARFOX experiment and implications for the aerosol single scattering albedo, J. Atmos. Sci., 59, 567-577, 2002.

Bergstrom, R. W., Pilewskie, P., Russell, P. B., Redemann, J., Bond, T. C., Quinn, P. K., and Sierau, B.: Spectral absorption properties of atmospheric aerosols, Atmos. Chem. Phys., 7, 5937-5943, 2007 , http://www.atmos-chem-phys.net/7/5937/2007/.

Boutton, T. W.: Stable carbon isotope ratios of natural materials II, Atmospheric, terrestial, marine, and freshwater environments, in: Carbon Isotope Techniiques, edited by: Coleman, D. C. and Fry, B., 173-183, 1991.

Cappiello, A., De Simoni, E., Fiorucci, C., Mangani, F., Palma, P., Trufelli, H., Decesari, S., Facchini, M. C., and Fuzzi, S.: Molecular characterization of the water-soluble organic compounds in fogwater by ESIMS/MS, Environ. Sci. Technol., 37, 1229-1240, 2003.

Castro, T., Madronich, S., Rivale, S., Muhlia, A., and Mar, B.: The influence of aerosols on photochemical smog in Mexico City, Atmos. Environ., 35, 1765-1772, 2001.

Craig, H.: Isotopic standards for carbon and oxygen and correction factors for mass-spectrometric analysis of carbon dioxide, Geochim. Cosmochim. Ac., 12, 133-149, 1957.

Coplen, T. B., Brand, W. A., Gehre, M., Gröning, M., Meijer, H. A. J., Toman, B., and Verkouteren, R. M.: After two decades a second anchor for the VPDB $\delta^{13} \mathrm{C}$ scale, Rapid Commun, Rapid Commun. Mass. Sp., 20, 3165-3166, 2006.

Currie, L. A., Klouda, G. A., and Gerlach, R. W.: Radiocarbon: Natures tracer for carbonaceous pollutants, in: Proceedings of the 1981 International Conference on Residential Solid Fuels: Environmental Impacts and Solutions, edited by: Cooper, J. A and Malek, D., Oregon Graduate Center, Beaverton, OR, USA, 365-385, 1982.

Decesari, S., Facchini, M. C., Matta, E., Mircea, M., Fuzzi, S., Chughtai, A. R., and Smith, D. M.: Water soluble organic com- 
pounds formed by oxidation of soot, Atmos. Environ., 36, 18271832, 2002.

de Foy, B., Varela, J. R., Molina, L. T., and Molina, M. J.: Rapid ventilation of the Mexico City basin and regional fate of the urban plume, Atmos. Chem. Phys., 6, 2321-2335, 2006, http://www.atmos-chem-phys.net/6/2321/2006/.

DeCarlo, P. F., Dunlea, E. J., Kimmel, J. R., Aiken, A. C., Sueper, D., Crounse, J., Wennberg, P. O., Emmons, L., Shinozuka, Y., Clarke, A., Zhou, J., Tomlinson, J., Collins, D. R., Knapp, D., Weinheimer, A. J., Montzka, D. D., Campos, T., and Jimenez, J. L.: Fast airborne aerosol size and chemistry measurements above Mexico City and Central Mexico during the MILAGRO campaign, Atmos. Chem. Phys., 8, 4027-4048, 2008, http://www.atmos-chem-phys.net/8/4027/2008/.

Dickerson, R. R., Kondragunta, S., Stenchikov, G., Civerolo, K. L., Doddridge, B. G., and Holben, N.: The impact of aerosols on solar ultraviolet radiation and photochemical smog, Science, 278, 827-8301997.

Dua, S. K., Hopke, P. K., and Raunemaa, T.: Hygroscopicity of Diesel Aerosols, Water Air Soil Poll., 112, 247-257, 1999.

Gaffney, J. S., Tanner, R. L., and Phillips, M.: Separating Carbonaceous Aerosol SourceTerms Using Thermal Evolution, Carbon Isotopic Measurements, and C/N/S Determinations, Sci. Total Environ., 36, 53-60, 1984.

Gaffney, J. S., Marley, N. A., Cunningham, M. M., and Doskey, P. V.: Measurements of Peroxyacyl Nitrates (PANs) in Mexico City: Implications for Megacity Air Quality Impacts on Regional Scales, Atmos. Environ., 33, 5003-5012, 1999.

Gaffney, J. S. and Marley, N. A.: Alternative Fuels, in Air Pollution Reviews: Volume 1, The Urban Air Atmosphere and Its Effects, edited by: Brimblecombe, P. and Maynard, R., Imperial College Press, London, UK, Chapter 6, 195-246, 2000.

Gaffney, J. S. and Marley, N. A. (eds.): The Importance of the Chemical and Physical Properties of Aerosols in Determining Their Transport and Residence Times in the Troposphere, Chapter 14, Urban Aerosols and Their Impacts: Lessons Learned from the World Trade Center Tragedy, ACS Symposium Book 919, Oxford University Press, 286-300, 2005.

Gelencsér, A., Hoffer, A., Kiss, G., Tombacz, E., Kurdi, R., and Bencze, L.: In-situ formation of light absorbing organic matter in cloud water, J. Atmos. Chem., 45, 25-33, 2003.

Gundel, L. A., Dod, R. L., Rosen, H., and Novakov, T.: The relationship between optical attenuation and black carbon concentration for ambient and source particles, Sci. Total Environ., 36, 197-202, 1984.

Hansen, A. D. A., Rosen, H., and Novakov, T.: Real-time measurement of the absorption coefficient of aerosol particles, Appl. Optics, 21, 3060-3062, 1982.

Hansen, A. D. A., Rosen, H., and Novakov, T.: The aethalometer: an instrument for the real-time measurement of optical absorption by aerosol particles, Sci. Total Environ., 36, 191-196, 1984.

Hermann, P. and Hanel, G.: Wintertime optical properties of atmospheric particles and weather, Atmos. Environ., 24, 4053-4062, 1997.

Hermann, M., Stratmann, M., Wilck, M. and Wiedensohler, A.: Sampling characteristics of an aircraft-borne aerosol inlet system, J. Am. Meteorol. Soc., 7-19, 2001.

Hennigan, C. J., Sullivan, A. P., Fountoukis, C. I., Nenes, A., Hecobian, A., Vargas, O., Peltier, R. E., Case Hanks, A. T., Huey, L.
G., Lefer, B. L., Russell, A. G., and Weber, R. J.: On the volatility and production mechanisms of newly formed nitrate and water soluble organic aerosol in Mexico City, Atmos. Chem. Phys., 8, 3761-3768, 2008,

http://www.atmos-chem-phys.net/8/3761/2008/.

Hildemann, L. M., Klinedinst, D. B., Klouda, G. A., Currie, L. A., and Cass, G. R.: Sources of urban contemporary carbon aerosol, Environ. Sci. Technol., 28, 1565-1576, 1994.

Hoffer, A., Gelencsér, A., Guyon, P., Kiss, G., Schmid, O., Frank, G. P., Artaxo, P., and Andreae, M. O.: Optical properties of humic-like substances (HULIS) in biomass-burning aerosols, Atmos. Chem. Phys., 6, 3563-3570, 2006,

http://www.atmos-chem-phys.net/6/3563/2006/.

Jacobson, M. Z.: Isolating nitrated and aromatic aerosols and nitrated aromatic gases as sources of ultraviolet light absorption, J. Geophys. Res., 104, 3527-3542, 1999.

Johnson, K. S., de Foy, B., Zuberi, B., Molina, L. T., Molina, M. J., Xie, Y., Laskin, A., and Shutthanandan, V.: Aerosol composition and source apportionment in the Mexico City Metropolitan Area with PIXE/PESA/STIM and multivariate analysis, Atmos. Chem. Phys., 6, 4591-4600, 2006,

http://www.atmos-chem-phys.net/6/4591/2006/.

Jordan, T. B., Seen, A. J., Jacobson, G. E., and Gras, J. L.: Radiocarbon determination of wood smoke contribution to air particulate matter in Launceston, Tasmania, Atmos. Environ., 40, 2575-2582, 2006.

Kaufman, Y. J., Tanré, D., and Boucher, O.: A satellite view of aerosols in the climate system, Nature, 419, 215-223, 2002.

Kiel. J. T. and Briegleb, B. P.: The relative roles of sulfate aerosols and greenhouse gases, Science, 260, 311-314, 1993.

Kirchstetter, T. W., Novakov, T., and Hobbs, P. V.: Evidence that the spectral dependence of light absorption by aerosols is affected by organic carbon, J. Geophys. Res., 109, D21208, doi:10.1029/2004JD004999, 2004.

Klinedinst, D. B. and Currie, L. A.: Direct quantification of $\mathrm{PM}_{2.5}$ fossil and biomass carbon within the Northern Front Range Air Quality study's domain, Environ. Sci. Technol., 33, 4146-4154, 1999.

Lewis, C. W. and Stiles, D. C.: Radiocarbon content of PM2.5 ambient aerosol in Tampa, FL, Aerosol Sci. Technol., 40, 189-196, 2006.

Lewis, C. W., Klouda, G. A., and Ellenson, W. D.: Radiocarbon measurement of the biogenic contribution to summertime PM-2.5 ambient aerosol in Nashville, TN, Atmos. Environ., 38, 6053-6061, 2004.

Limbeck, A., Kulmala, M., and Puxbaum, H.: Secondary organic aerosol formation in the atmosphere via heterogeneous reaction of gaseous isoprene on acidic particles, Geophys. Res. Lett., 30, ASC6.1-ASC6.4, doi:10.1029/2003GL017738, 2003.

Mang, S. A., Henricksen, D. K., Bateman, A. P., Andersen, M. P. S., Blake, D. R., and Nizkorodov, S. A.: Contribution of carbonyl photochemistry to aging of atmospheric secondary organic aerosol, J. Phys. Chem. A, 112, 8337-8344, 2008.

Marley, N. A., Gaffney, J. S., Baird, J. C., Blazer, C. A., Drayton, P. J., and Frederick, J. E.: An empirical method for the determination of the refractive index of size fractionated atmospheric aerosols for radiative transfer calculations, Aerosol Sci. Technol., 34, 535-549, 2001.

Massie, S. T., Gille, J. C., Edwards, D. P., and Nandi, S.: Satel- 
lite observations of aerosol and $\mathrm{CO}$ over Mexico City, Atmos. Environ., 40, 6019-6031, 2006.

Meloni, D., di Sarra, A., Pace, G., and Monteleone, F.: Aerosol optical properties at Lampedusa (Central Mediterranean). 2. Determination of single scattering albedo at two wavelengths for different aerosol types, Atmos. Chem. Phys., 6, 715-727, 2006, http://www.atmos-chem-phys.net/6/715/2006/.

Moffet, R. C., de Foy, B., Molina, L. T., Molina, M. J., and Prather, K. A.: Measurement of ambient aerosols in northern Mexico City by single particle mass spectrometry, Atmos. Chem. Phys., 8, 4499-4516, 2008, http://www.atmos-chemphys.net/8/4499/2008/.

Park, K., Chow, J. C., Watson, J. G., Trimble, D. L., Doraiswamy, P., Arnott, W. P., Stroud, K. R., Bowers, K., Bode, R., Petzold, A., and Hansen, A. D. A.: Comparison of continuous and filterbased carbon measurements at the Fresno Supersite, J. Air Waste Manage., 56, 474-491, 2006.

Paredes-Miranda, G., Arnott, W. P., Jimenez, J. L., Aiken, A. C., Gaffney, J. S., and Marley, N. A.: Primary and secondary contributions to aerosol light scattering and absorption in Mexico City during the MILAGRO 2006 campaign, Atmos. Chem. Phys. Discuss., 8, 16951-16979, 2008, http://www.atmos-chem-physdiscuss.net/8/16951/2008/.

Pinnick, R. C., Hill, S. C, Pan, Y.-L., and Chang, R. K.: Fluorescence spectra of atmospheric aerosol at Adelphi, Maryland, USA: measurement and classification of single particles containing organic carbon, Atmos. Environ., 38, 1657-1672, 2004.

Raga, G. B., Baumgardner, D., Castro, T., Martìnez-Arroyo, A., and Navarro-González, R.: Mexico City air quality: a qualitative review of gas and aerosol measurements (1960-2000), Atmos. Environ., 35, 4041-4058, 2001.

Ramanathan, V., Ramana, M. V., Roberts, G., Kim, D., Corrigan, C. E., Chung C. E., and Winker, D.: Warming trends I Asia amplified by brown cloud solar absorption, Nature, 448, 575-578, 2007.

Ramanathan, V. and Carmichael, G.: Global and regional climate changes due to black carbon, Nature, 1, 221-227, 2008.

Rowe, M. W. and Steelman, K. L.: Radiocarbon dating of rock paintings using plasma-chemical extraction, Am. Lab., 34, 1519, 2002.

Sage, R. F.: Environmental and evolutionary preconditions for the origin and diversification of the C-4 photosynthetic syndrome, Plant Biol., 3, 202-213, 2001.

Salcedo, D., Onasch, T. B., Dzepina, K., Canagaratna, M. R., Zhang, Q., Huffman, J. A., DeCarlo, P. F., Jayne, J. T., Mortimer, P., Worsnop, D. R., Kolb, C. E., Johnson, K. S., Zuberi, B., Marr, L. C., Volkamer, R., Molina, L. T., Molina, M. J., Cardenas, B., Bernabé, R. M., Márquez, C., Gaffney, J. S., Marley, N. A., Laskin, A., Shutthanandan, V., Xie, Y., Brune, W., Lesher, R., Shirley, T., and Jimenez, J. L.: Characterization of ambient aerosols in Mexico City during the MCMA-2003 campaign with Aerosol Mass Spectrometry: results from the CENICA Supersite, Atmos. Chem. Phys., 6, 925-946, 2006, http://www.atmoschem-phys.net/6/925/2006/.

Schmid, O., Artaxo, P., Arnott, W. P., Chand, D., Gatti, L. V., Frank, G. P., Hoffer, A., Schnaiter, M., and Andreae, M. O.: Spectral light absorption by ambient aerosols influenced by biomass burning in the Amazon Basin. I: Comparison and field calibration of absorption measurement techniques, Atmos.
Chem. Phys., 6, 3443-3462, 2006, http://www.atmos-chemphys.net/6/3443/2006/.

Smith, B. N. and Epstein, S.: Two categories of ${ }^{13} \mathrm{C} /{ }^{12} \mathrm{C}$ ratios for higher plants, Plant Physiol., 47, 380-384, 1971.

Stone, E. A., Snyder, D. C., Sheesley, R. J., Sullivan, A. P., Weber, R. J., and Schauer, J. J.: Source apportionment of fine organic aerosol in Mexico City during the MILAGRO experiment 2006, Atmos. Chem. Phys., 8, 1249-1259, 2008, http://www.atmoschem-phys.net/8/1249/2008/.

Stuiver, M. and Polach, H. A.: Discussion: Reporting of ${ }^{14} \mathrm{C}$ data, Radiocarbon, 19, 355-365, 1977.

Szidat, S., Jenk, T. M., Gäggeler, H. W., Synal, H.-A., Fisseha, R., Baltensperger, U., Kalberer, M., Samburova, V., Wacker, L., Saurer, M., Schwikowski, M., and Hajdas, I.: Source apportionment of aerosols by ${ }^{14} \mathrm{C}$ measurements in different carbonaceous particle fractions. Radiocarbon, 46, 475-484, 2004.

Takahashi, K., Hirabayashi, M., Tanabe, K., Shibata, Y., Nishikawa, M., and Sakamoto, K.: Radiocarbon content in urban atmospheric aerosols, Water Air Soil Poll., 185, 305-310, 2007.

Tang, Y., Carmichael, G. R., Uno, I., Kurata, G., Lefer, B., Shetter, R. E., Huang, H., Anderson, B. E., Avery, M. A., Clarke, A. D., and Blake, D. R.: Impacts of aerosols and clouds on photolysis frequencies and photochemistry during TRACE-P:2. Threedimensional study using a regional chemical transport model, J. Geophys. Res., 108, 8822, doi:10.1029/2002JD003,2003, 2003.

Torres, O., Bhartia, P. K., Herman, J. R., Ahmad, Z., and Gleason, J.: Derivation of aerosol properties from satellite measurements of backscattered ultraviolet radiation. Theoretical basis, J. Geophys. Res., 103, 17099-17110, 1998.

Volkamer, R., Jimenez, J. L., San Martini, F., Dzpina, F., Zhang, Q., Salcedo, D., Molina, L. T., Worsnop, D. R., and Molina, M. J.: Secondary organic aerosol formation from anthropogenic air pollution: Rapid and higher than expected, Geophys. Res. Lett., 33, L17811, doi:10.1029/2006GL026899, 2006.

Walser, M. L., Park, J., Gomez, A. L., Russell, A. R., and Nizkorodov, S. A.: Photochemical aging of secondary organic aerosol particles generated from the oxidation of d-limonene, J. Phys. Chem. A, 111, 1907-1913, 2007.

Wendisch, M., Mertes, S., Ruggaber, A., and Nakajima, T.: Vertical profiles of aerosol and radiation and the influence of a temperature inversion: Measurements and radiative transfer calculations, J. Appl. Meteorol., 35, 1703-1715, 1996.

Yokelson, R. J., Urbanski, S. P., Atlas, E. L., Toohey, D. W., Alvarado, E. C., Crounse, J. D., Wennberg, P. O., Fisher, M. E., Wold, C. E., Campos, T. L., Adachi, K., Buseck, P. R., and Hao, W. M.: Emissions from forest fires near Mexico City, Atmos. Chem. Phys., 7, 5569-5584, 2007, http://www.atmoschem-phys.net/7/5569/2007/.

Yokelson, R., Crounse, J. D., DeCarlo, P. F., Karl, T., Urbanski, S., Atlas, E., Campos, T., Shinozuka, Y., Kapustin, V., Clarke, A. D., Weinheimer, A., Knapp, D. J., Montzka, D. D., Holloway, J., Weibring, P., Flocke, F., Zheng, W., Toohey, D., Wennberg, P. O., Wiedinmyer, C., Mauldin, L., Fried, A., Richter, D., Walega, J., Jimenez, J. L., Adachi, K., Buseck, P. R., Hall, S. R., and Shetter, R.: Emissions from biomass burning in the Yucatan, Atmos. Chem. Phys. Discuss., 9, 767-835, 2009, http://www.atmoschem-phys-discuss.net/9/767/2009/. 